\title{
How students perceive problem-based learning (PBL) group tutorials at a Swedish Medical College
}

\author{
Zoltán Szabó, Márta Harangi, Eva Nylander, Anders Ljungman, Annette Theodorsson, \\ Henrik Ahn and Bo Davidsson
}

Linköping University Post Print

\section{Tweet}

N.B.: When citing this work, cite the original article.

Original Publication:

Zoltán Szabó, Márta Harangi, Eva Nylander, Anders Ljungman, Annette Theodorsson, Henrik Ahn and Bo Davidsson, How students perceive problem-based learning (PBL) group tutorials at a Swedish Medical College, 2015, Med Ed Publish, (6), 17. http://dx.doi.org/10.15694/mep.2015.006.0017

Copyright: The Authors.

http://www.mededworld.org/

Postprint available at: Linköping University Electronic Press

http://urn.kb.se/resolve?urn=urn:nbn:se:liu:diva-122164 


\section{How Students Perceive Problem-Based Learning (PBL) Group Tutorials at a Swedish Medical College.}

\section{Zoltán Szabó, Márta Harangi, Eva Nylander, Anders Ljungman, Annette Theodorsson, Henrik Ahn and Bo Davidsson}

Corresponding author: Zoltán Szabó zoltan.szabo@ regionostergotland.se

Department: Dept. of Cardiothoracic Anesthesia, Linköping Heart Center, University Hospital, S-581 85 Linköping, Sweden.

Received: 21/09/2015

Accepted: 22/09/2015

Published: 29/09/2015

\section{Abstract}

Introduction: student perception of problem-based learning (PBL) group tutorials was investigated at a Swedish University Medical College 27 years after the introduction of PBL into the curriculum.

Methods: a survey questionnaire comprising 43 questions answered on a Likert-type scale, together with one open question was used. The questionnaire was distributed to all 821 students taking part in the Linköping University medical program at the beginning of the Spring Term 2013. The results were subjected to explorative factor analysis, descriptive statistics and ANOVA. Responses to the open question where analyzed qualitatively by categorization.

Results: 84 per cent of the 821 students completed the survey. Four factors describing student perception were identified: 1) PBL as a method of learning; 2) the tutor's role; 3) PBL, stress and feelings of insecurity; and 4) traditional teaching methods within the PBL curriculum. The Cronbach's alpha value was 0,788 overall. Two hundred and seventy-six students answered the open question declaring that they would appreciate more precise aims and objectives, smaller tutorial groups, and more formal lectures.

Conclusions: the results of this study on PBL group tutorials, as seen from the student's perspective, stress the importance of tutorial quality, tutor competence, tutorial group size and the quality and aims of the curriculum. Too much emphasis on the teacher's research merits against the educational ones, and the inability to adapt to the needs and wishes of new generations of students seems a probable cause for the erosion of PBL.

Keywords: Problem-based learning, group work, tutors, self-directed learning

\section{Article}

\section{Introduction}

PBL has its roots in the pragmatism of John Dewey claiming that knowledge is developed in relation to its usefulness and practicality. This is expressed in the catch-phrase "learning by doing" as theory and practice are closely interrelated(Dewey, 1928). The PBL method was developed by Howard Barrows and tailored for medical education in 1980 (Barrows, 1980). Hammar Chiriac states that group work is used both as the objective and the means in PBL (Hammar Chiriac, 2014). The principle of studying in groups assumes the 
Szabó Z, Harangi M, Nylander E, Ljungman A, Theodorsson A, Ahn H and Davidsson B. MedEdPublish 2015, 6: 17

http://dx.doi.org/10.15694/mep.2015.006.0017

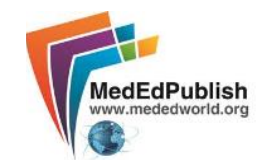

student's motivation to learn. Working in a PBL group has the advantage of social facilitation( $\underline{\text { Hammar }}$ Chiriac, 2014).

In practice, however, working in groups may falter due to the students, the tutor or both. Common studentrelated problems include: dysfunctional groups; shy individuals; dominant students; and non-attendance (Tarnvik, 2007). Lack of self-discipline necessary for self-directed learning (Barrows, 1980), lack of motivation, and personal problems lead to failure of the PBL method (Schwartz P, 2001). Recognition of tutor-related problems and measures taken are at the heart of maintaining and improving the quality of PBL as pointed out by Azer et al (Azer, McLean, Onishi, Tagawa, \& Scherpbier, 2013).

In 1986 the Medical Faculty of Linköping University was amongst the first in Europe to employ PBL. The exponential increase in knowledge in a rapidly changing world created the need to turn academic education towards self-directed learning centered on the student (Rawlings, 2012). Although major revision of the curriculum was made and implemented 2003, tutorial groups continue to perform suboptimal, not only due to the students but also the tutors (Harangi, 2011).

A comprehensive survey of all medical college students was therefore carried out during the Spring Term of 2013 in order to investigate how they perceived working in tutorial groups. Our aim was to find out which factors are important in influencing this issue as well how these factors change from term to term over the course of the medical program from Term 1 to Term 11 (two terms a year).

\section{Methods}

The population studied consisted of all medical students at Linköping University Medical College during the Spring Term of 2013. The study was approved by the Regional Ethics Review Board in Linköping, Sweden (Dnr. 2012/298-31).

The medical program comprises 11 terms and PBL is used for all courses. The program is divided into three stages; Stage 1 (Terms 1 -2), Stage 2 (Terms 3 -5), and Stage 3 (Terms 6 - 11). Tutors are engaged in group work Terms 1 to 5. Thereafter the students conduct group work themselves. This study included students from Terms 6 - 11 since they had a broad perspective and experience of group tutorials in the first two stages.

The survey questionnaire comprised 43 questions answered on a Likert-type scale. Plain Swedish language without negations was used. The Likert-type scale had four points: $1=$ totally disagree; $2=$ tend to disagree; $\mathbf{3}=$ tend to agree; $\mathbf{4}=$ totally agree. The questionnaire finished with an open question concerning student perception of group tutorials and suggestions for improvement in the future. The total number of active students at the time of the survey was 821 . Of these 687 answered, i.e. a response rate of 84 per cent. SPSS was used for statistical evaluation of the data (SPSS, 2012), and the results presented as mean with standard deviation (SD). A standard variant of explorative factor analysis using Kaiser's criterion followed by Varimax rotation was used(Pedhazur E. J., 1991). To elicit any tendencies between terms in the program, the means for each factor for each Stage of the program were analyzed using one-way ANOVA, combined with the Bonferroni post hoc test (IBM SPSS statistic standard 20. 2012).

The answers to the open question were analysed qualitatively using categorization. As the number of responses was large, we were forced to reduce the volume of the analysis and aim for overall tendencies rather than depth. At the same time the analysis had to be sensitive to nuances. The analysis was therefore performed in two phases. In the first phase the answers were read through repeatedly until a pattern of categories began to emerge. All student statements were then coded into the three main categories and divided for each term. In the second phase the statements in each of the main categories were sorted into sub-categories resulting in a matrix (Bryman, 2011; Miles, 2013) of categories according to Term, making it possible to interpret the responding students' overall perception of PBL, as well as trends from Stage to Stage. 
Szabó Z, Harangi M, Nylander E, Ljungman A, Theodorsson A, Ahn H and Davidsson B. MedEdPublish 2015, 6: 17

http://dx.doi.org/10.15694/mep.2015.006.0017

\section{Results}

Factor analysis yielded four factors which reflected the logic of the survey. We named the factors: 1) PBL as a method for learning; 2) The tutor's role; 3) PBL, stress and feelings of insecurity; and 4) Traditional teaching methods within the PBL program. Cronbach alpha reliability coefficients for the four factors were calculated and found to be: Factor 1, 0,919; Factor 2, 0,919; Factor 3, 0,740; and Factor 4, 0,574, giving an overall reliability of 0,788 for the four factors. The means and standard deviations for the factors covering the whole group of respondents are presented in Table 1.

Table 1.

\begin{tabular}{lccc}
\hline Factor & $\mathbf{N}$ & Mean & Std. Deviation \\
\hline $\begin{array}{l}\text { Factor1. PBL as a method } \\
\text { of learning }\end{array}$ & 562 & 3,222 &, 541 \\
$\begin{array}{l}\text { Factor 2. The tutor's role as } \\
\text { a help in learning }\end{array}$ & 479 & 2,763 &, 652 \\
$\begin{array}{l}\text { Factor 3. PBL, stress and } \\
\text { feelings of insecurity }\end{array}$ & 618 & 2,753 &, 613 \\
$\begin{array}{l}\text { Factor 4. Traditional } \\
\text { teaching methods }\end{array}$ & 629 & 2,893 &, 508 \\
\hline
\end{tabular}

The results may be interpreted as follows: the mean for Factor 1, PBL as a method of learning, was 3,222, i.e. slightly above the alternative "tend to agree", implying that the students value PBL as a method based on relevant cases that stimulates cooperation and learning. The mean for Factor 2, concerning the tutor's role in helping learning, was 2,763 implying that the students perceived their tutors as being helpful in PBL, but not as much as the method itself. The mean for Factor 3, covering how PBL leads to stress, insecurity and uncertainty caused by discussions in the group and difficulty in searching literature, was 2,753, implying that although PBL is perceived as being positive, and tutor's as generally supportive, PBL is also a source of considerable uncertainty and stress. Finally, the mean for Factor 4, traditional teaching methods within the PBL curriculum, i.e. lectures and clinical practice was 2,893, implying that the students rate traditional teaching methods as good as PBL.

In order to elicit tendencies with time from Stage to Stage in the program, differences between the three stages were calculated using one-way ANOVA, combined with the Bonferroni post hoc test. Details of the whole model are presented in Table 2, the post hoc results are included in Appendix 1.

Table 2.

\begin{tabular}{lcccc}
\hline & & & & \\
\hline Factor 1. PBL as a method of & Stage 1 & 145 & 3,431 &, 414 \\
learning & Stage 2 & 156 & 3,323 &, 429 \\
& Stage 3 & 261 & 3,046 &, 605 \\
\hline Factor 2. The tutor's role as & Stage 1 & 136 & 3,050 &, 623 \\
help in learning & Stage 2 & 155 & 2,746 &, 670 \\
& Stage 3 & 188 & 2,571 &, 635 \\
\hline Factor 3. PBL, stress and & Stage 1 & 168 & 2,871 &, 621 \\
feelings of insecurity & Stage 2 & 173 & 2,695 &, 568
\end{tabular}


Szabó Z, Harangi M, Nylander E, Ljungman A, Theodorsson A, Ahn H and Davidsson B. MedEdPublish 2015, 6: 17

http://dx.doi.org/10.15694/mep.2015.006.0017

\begin{tabular}{lllll}
\hline & Stage 3 & 277 & 2,718 &, 628 \\
\hline Factor 4. Traditional teaching & Stage 1 & 164 & 2,736 &, 493 \\
methods & Stage 2 & 180 & 2,859 &, 493 \\
& Stage 3 & 285 & 3,005 &, 500 \\
\hline
\end{tabular}

Regarding Factor 1, the overall tendency was that student appreciation of PBL as a learning method decreases the further they progress in the program. This decrease in appreciation was significant $(\mathrm{F}=30,250 ; \mathrm{df}=2: 561$; $\mathrm{p}=.000$ ). It must be emphasized that Factor 2, regarding the tutor's role as supportive in learning, was only directly relevant for the first five terms in the program, i.e. Stages 1 and 2, as tutors are not involved in the PBL program during the last six terms. However students from Stage 3 had a general picture of the tutoring system from previous Stages. Even here we saw a significant decrease in student appreciation with time $(\mathrm{F}=23,356 ; \mathrm{df}=2 ; 478 ; \mathrm{p}=.000)$. Regarding Factor 3, i.e. PBL, stress and feelings of insecurity, the student ratings were highest during Stage 1, fell during Stage 2, and rose slightly again during Stage 3 . The differences between Stages were significant $(\mathrm{F}=4,402 ; \mathrm{df}=2: 617 ; \mathrm{p}=.013)$. For Factor 4, i.e. traditional teaching methods, there was a clear trend in student rating of importance between the three stages, lectures and clinical practice being more and more appreciated as time went by; the difference was significant $(\mathrm{F}=15,849 ; \mathrm{df}=2: 628 ; \mathrm{p}=.000)$.

\section{Student responses to the open question}

The responses of the students to the open question were analyzed qualitatively using a method of categorization. The three main categories were: 1 . Overall appreciation of PBL tutorial groups, aims and objectives; 2. tutor competence and involvement; and 3.

PBL organization. There were 299 statements, 151, 82 and 66 regarding Categories 1,2 and 3 respectively.

Category 1. Overall appreciation of PBL tutorial groups, aims and objectives In this category (Table 3) nearly all of the answers were critical of PBL or how PBL is applied in the medical program. The most common sub-category, namely that aims and objectives need to be better formulated, were roughly the same for each of the three stages, indicating a rather uniform opinion. Other frequent statements concerned the large size of the tutorial groups and the desire for more lectures. An interesting pattern was that the students' perception, that PBL is not always a suitable method, became greater in the later stages of the program.

Table 3.

\begin{tabular}{|c|c|c|}
\hline Stage & Statements (N) & Sub categories \\
\hline 1 & 34 & $\begin{array}{l}\text { - Aims and objectives need to be better formulated. } \\
\text { - Tutorial groups need more time/longer periods. } \\
\text { - Lectures are better. }\end{array}$ \\
\hline 2 & 43 & $\begin{array}{l}\text { - } \quad \text { Aims and objectives need to be better formulated. } \\
\text { - Tutorial groups should be smaller. } \\
\text { - } \quad \text { Lectures are better. }\end{array}$ \\
\hline 3 & 74 & $\begin{array}{l}\text { - } \quad \text { Aims and objectives need to be better formulated. } \\
\text { - Smaller tutorial groups. } \\
\text { - } \quad \text { More lectures. } \\
\text { - } \quad \text { PBL is better suited later in the program. } \\
\text { - } \quad \text { PBL should be optional. } \\
\text { - } \quad \text { PBL and traditional teaching methods need to be balanced. }\end{array}$ \\
\hline 4 & 151 & $\begin{array}{l}\text { - } \quad \text { Aims and objectives need to be better formulated. } \\
\text { - } \quad \text { PBL is not suitable for every course/moment. } \\
\text { - } \quad \text { Smaller tutorial groups. } \\
\text { More and better lectures. }\end{array}$ \\
\hline
\end{tabular}


Szabó Z, Harangi M, Nylander E, Ljungman A, Theodorsson A, Ahn H and Davidsson B. MedEdPublish 2015, 6: 17

http://dx.doi.org/10.15694/mep.2015.006.0017

Category 2. Tutor competence and involvement -The second category covered tutors, their competence and involvement (Table 4). One sub-category predominated; that the quality of the tutor varies. The students also described their tutors as not being involved enough. Some named that senior students might perform better as tutors. In this category, as well as in the first, there was a tendency that the sub-categories became slightly more diverse in the last two stages in the program.

Table 4.

\begin{tabular}{|c|c|c|}
\hline Stage & Statements (N) & Sub categories \\
\hline 1 & 13 & - The quality of the tutors is uneven. \\
\hline 2 & 25 & $\begin{array}{l}\text { - The quality of the tutors is uneven. } \\
\text { - } \quad \text { Tutors need to be better prepared. }\end{array}$ \\
\hline 3 & 44 & $\begin{array}{l}\text { - } \quad \text { The quality of the tutors is uneven. } \\
\text { - } \quad \text { Tutors are often unengaged. } \\
\text { - } \quad \text { Tutors need to be more involved. } \\
\text { - } \quad \text { Tutors need more competence. } \\
\text { - } \quad \text { PBL requires good tutors. } \\
\text { - } \quad \text { Vignettes/cases need to be updated. } \\
\text { - } \quad \text { Senior students are better as tutors. }\end{array}$ \\
\hline Total & 82 & $\begin{array}{l}\text { - The quality of the tutors is uneven. } \\
\text { - } \quad \text { Tutors are often unengaged. }\end{array}$ \\
\hline
\end{tabular}

Category 3. PBL organization - The third main category concerned the organisation of PBL at our medical college (Table 5). This category received the least number of statements and no clear pattern was seen between stages. Even here, as in the first category, the opinion that PBL is not always a suitable method persisted. Students desired better coordination between lectures and group tutorials in the program.

Table 5 .

\begin{tabular}{|c|c|c|}
\hline Stage & $\begin{array}{l}\text { Statements } \\
(\mathrm{N})\end{array}$ & Sub categories \\
\hline 1 & 6 & $\begin{array}{ll}\text { - } & \text { Better overall structure. } \\
\text { - } & \text { Better homepage. } \\
\text { - } & \text { Frequent small examinations. } \\
\end{array}$ \\
\hline 2 & 32 & $\begin{array}{l}\text { - } \text { PBL is not suitable for every course/moment. } \\
\text { - Better connection between lectures and work in tutorial groups. } \\
\text { - Need for flexibility regarding participation in tutorial groups - not } \\
\text { punishment! } \\
\text { - } \quad \text { PBL is good! }\end{array}$ \\
\hline 3 & 28 & $\begin{array}{l}\text { - } \quad \text { Better connection between lectures and work in tutorial groups. } \\
\text { - } \quad \text { No PBL in the clinical term. } \\
\text { - } \quad \text { More vignettes/cases. } \\
\text { - } \quad \text { More lectures. } \\
\text { - } \quad \text { Better feedback. }\end{array}$ \\
\hline Total & 66 & $\begin{array}{l}\text { - } \quad \text { PBL is not suitable for every course/moment. } \\
\text { - } \quad \text { Better connection between lectures and work in tutorial groups. }\end{array}$ \\
\hline
\end{tabular}

\section{Discussion}

When sounding student opinion regarding PBL at our medical college, four major factors were defined: Factor 1, PBL as a method of learning; Factor 2, the role played by the tutor; Factor 3, stress and feelings of insecurity resulting from PBL and Factor 4, traditional teaching methods in relation to PBL. 
Szabó Z, Harangi M, Nylander E, Ljungman A, Theodorsson A, Ahn H and Davidsson B. MedEdPublish 2015, 6: 17

http://dx.doi.org/10.15694/mep.2015.006.0017

Regarding Factor 1, the students "tended to agree" that PBL is a useful learning method.

Regarding Factor 2, the students perceived their tutors as being helpful in PBL, but not as much as the method itself.

Regarding Factor 3, PBL causes stress and feelings of insecurity. This agrees with the results of others in the few papers published on stress and PBL. When Lewis compared traditional teaching methods with PBL, PBL was found to be a source of considerable stress (Lewis et al., 2009). This was also described by Moffat in first-year medical students (Moffat, McConnachie, Ross, \& Morrison, 2004). We did not investigate coping in this student group, as the study was not designed to explore that issue. However it is possible that improvements in curriculum design and better formulated aims could give the students more security in learning and consequently diminish feelings of stress.

Regarding Factor 4, lectures and clinical practice were considered the most important sources of knowledge. The students perceived traditional teaching methods as being almost as good as PBL in the later stages.

The student commented that they needed better formulated aims and objectives, smaller tutorial groups and more lectures. They also felt that the quality of tutors varied, and that their tutors were not involved enough. Some considered that senior students might perform better as tutors, and others that PBL is not suitable in all situations. In the students' opinion coordination between lectures and tutorials needs to be improved.

At the beginning of the medical program PBL was regarded as a relevant and useful method of learning. This held for the duration of the program, but appreciation declined as time went by. This decrease in appreciation regarding PBL coincided with a decrease in the students' faith in the role of the tutor and an increase in their appreciation of traditional teaching methods, the latter being regarded as equal by the end of the program. This trend is not necessarily negative as it may be a sign of a student's intellectual maturation and increase in autonomy during the years at the medical college. Of course this pattern can be interpreted in a number of ways, but the tutor's role, or rather the absence of tutors in Stage 3of the medical program, may be one possible reason for the decrease in student appreciation of PBL and their increased trust in traditional teaching methods. The exact explanation can only be elucidated by a qualitative study. Similar results led Moust to the conclusion that this is a sign of PBL erosion (J. H. C. Moust, Van Berkel, \& Schmidt, 2005) and proposed new ways to revitalize PBL groups (J. Moust, Roebertsen, Savelberg, \& De Rijk, 2005). In our opinion these are very good suggestions based on pertinent analyses. We also suggest that better coordination between PBL tutorials and clinical teaching could also revitalize trust in PBL later on in the curriculum at Linköping Medical College.

Our results indicate that PBL during the early terms of a medical curriculum may increase student autonomy. Students may change their behaviour when embarking on the clinical stage (Terms 6 and upwards) as they have more contact with physicians and therefore develop role models on how to get information and how to reflect on it. Most physicians in clinical practice still use traditional teaching methods for lifelong learning. That role model may influence student behaviour and could at least partly explain our results. This may be one of the reasons why Harvard Medical School has introduced a more structured PBL(Cardozo, Raymond, \& White, 2012). Even our students in response to the open question stated a lack of clearly formulated study aims and objectives.

Developing curricula to better fit student requirements may diminish student stress and improve learning in a medical program. In a mixed PBL curriculum where web-based learning was combined with PBL, the students were very positive (Woltering, Herrler, Spitzer, \& Spreckelsen, 2009) and this may well be one of the ways to improve PBL in the future.

There are relatively few studies in the literature on student perception of the use of PBL in different contexts. One studied the opinion of students at the time of introduction of PBL (Bernstein, Tipping, Bercovitz, \& Skinner, 1995; McCourt \& Gail Thomas, 2001). Bernstein et al reported that "The students rated traditional methods as better for knowledge acquisition, whereas PBL methods were rated better for improving teamwork and doctor-patient relationships" (Bernstein et al., 1995). This implies that different aspects of medical education can be handled with different methods of teaching/learning. 
Szabó Z, Harangi M, Nylander E, Ljungman A, Theodorsson A, Ahn H and Davidsson B. MedEdPublish 2015, 6: 17

http://dx.doi.org/10.15694/mep.2015.006.0017

Senevirante et al studied student perception of PBL in a new curriculum. The response frequency was high and answers showed that the students perceived PBL as time-consuming. Half of the students felt that PBL improved communication and problem-solving skills and almost half were satisfied with group tutorials (Seneviratne, Samarasekera, Karunathilake, \& Ponnamperuma, 2001). That study is not directly comparable with ours as the numbers of responders was about a third of that in our survey, and the issues of that study were quite different. Ragab in his study compared the preferences and learning outcomes of medical students between PBL and traditional lectures and found that students preferred PBL. His conclusion was that introduction of a hybrid-PBL curriculum was to be highly recommended (Ragab Ibrahim et al., 2014).

The main limitation of our study is the same as of all quantitative studies, but it does reveal the weakness of PBL as practised at our Medical College, and raises issues which have to be examined using qualitative methods. As the open question was answered by roughly one third of the students completing the questionnaire, their responses do hint at the true situation but they have to be interpreted with caution. One possibility, for instance, is that the students who answered the open question are those who chose to voice criticism regarding PBL or the medical program, while positive or indifferent students chose not to answer.

\section{Conclusion}

We defined four factors which describe how students perceive work in PBL tutorial groups at our Medical School, namely: 1. PBL as a method for learning; 2 . the tutor's role; 3 . PBL,stress and feelings of insecurity; and 4. coupling of PBL to traditional teaching methods.

One third of the students completing the survey questionnaire responded to the open question. They expressed the wish to have better formulated aims and objectives, smaller tutorial groups and more formal lectures, and they felt that PBL does not suit all courses/moments in the curriculum. The students also complained that the quality of tutors varies, and described their tutors as not being involved enough, and suggested that senior students might perform better as tutors. Finally coordination between lectures and tutorial groups throughout the medical program must be improved.

\section{Acknowledgements}

We thank Mr. Olof Malm for his exemplary registration of data in the database. Those in the "Network for lecturers at the medical college in Linköping" who, in collaboration with other teachers from the medical program and the Institution of Behavioral Sciences, initiated the survey. Special thanks to the Dean of the medical college for his support in distributing the surveys.

Disclaimer: none

\section{Notes on Contributors:}

Zoltán Szabó MD. PhD1, is part of the Division of Cardiovascular Medicine, Department of Medical and Health Sciences, Faculty of Health Sciences, Linköping University, Department of Thoracic and Vascular Surgery, Heart and Medicine Center, County Council of Östergötland.

Márta Harangi MS.2, is part of the from 2Linköping, Sweden.

Eva Nylander MD. PhD3, is part of the Department of Clinical Physiology and Department of Medical and Health Sciences, Linköping University.

Anders Ljungman PhD6, is part of the Division of Neuro and Inflammation Sciences, Faculty of Medicine and Health Sciences. Linköping University, SE-581 85 Linköping, Sweden. 
Szabó Z, Harangi M, Nylander E, Ljungman A, Theodorsson A, Ahn H and Davidsson B. MedEdPublish 2015, 6: 17

http://dx.doi.org/10.15694/mep.2015.006.0017

Annette Theodorsson MD. PhD4, is part of the Neurosurgery, Department of Clinical and Experimental Medicine, Faculty of Health Sciences, Linköping University, Department of Neurosurgery, County Council of Östergötland, Linköping, Sweden.

Henrik Ahn MD. PhD1, is part of the Division of Cardiovascular Medicine, Department of Medical and Health Sciences, Faculty of Health Sciences, Linköping University, Department of Thoracic and Vascular Surgery, Heart and Medicine Center, County Council of Östergötland.

Bo Davidsson PhD5, is part of the Department of Behavioral Sciences and Learning, Linköping University, Linköping, Sweden 6 Division of Neuro and Inflammation Sciences, Faculty of Medicine and Health Sciences. Linköping University, SE-581 85 Linköping, Sweden. 
Szabó Z, Harangi M, Nylander E, Ljungman A, Theodorsson A, Ahn H and Davidsson B. MedEdPublish 2015, 6: 17

http://dx.doi.org/10.15694/mep.2015.006.0017

\section{References}

Azer, S. A., McLean, M., Onishi, H., Tagawa, M., \& Scherpbier, A. (2013). Cracks in problem-based learning: what is your action plan? Med Teach, 35(10), 806-814. doi: 10.3109/0142159x.2013.826792 http://dx.doi.org/10.3109/0142159X.2013.826792

Barrows, H. S. T. R. M. (1980). Problem-based learning. An Approach to Medical Education. New York: Springer Publishing Company.

Bernstein, P., Tipping, J., Bercovitz, K., \& Skinner, H. A. (1995). Shifting students and faculty to a PBL curriculum: attitudes changed and lessons learned. Acad Med, 70(3), 245-247.

http://dx.doi.org/10.1097/00001888-199503000-00019

Bryman, A. (2011). Samhällsvetenskapliga metoder. Malmö: Lieber.

Cardozo, D. L., Raymond, L., \& White, B. (2012). A structured PBL tutorial involving small teams for teaching the human nervous system. Med Teach, 34(11), e763-771. doi: 10.3109/0142159x.2012.691187 http://dx.doi.org/10.3109/0142159X.2012.691187

Dewey, J. (1928). Body and Mind. Bull N Y Acad Med, 4(1), 3-19.

Hammar Chiriac, E. (2014). Group work as an incentive for learning - students' experiences of group work. Front Psychol, 5, 558. doi: 10.3389/fpsyg.2014.00558

http://dx.doi.org/10.3389/fpsyg.2014.00558

Harangi, M. (2011). PBL ur en studentperspektiv: En kvantitativ studie vid Hälsouniversitetet, Linköpings Universitet. Linköpings University, Linköping Sweden.

Lewis, A. D., Menezes, D. A., McDermott, H. E., Hibbert, L. J., Brennan, S. L., Ross, E. E., \& Jones, L. A. (2009). A comparison of course-related stressors in undergraduate problem-based learning (PBL) versus nonPBL medical programmes. BMC Med Educ, 9, 60. doi: 10.1186/1472-6920-9-60

http://dx.doi.org/10.1186/1472-6920-9-60

McCourt, C., \& Gail Thomas, B. (2001). Evaluation of a problem-based curriculum in midwifery. Midwifery, 17(4), 323-331. doi: 10.1054/midw.2001.0276

http://dx.doi.org/10.1054/midw.2001.0276

Miles, M. B., Huberman A. M, Saldana J. (2013). Qualitative Data Analysis A Method Sourcebook 3d Ed.: Sage Pblications Inc.

Moffat, K. J., McConnachie, A., Ross, S., \& Morrison, J. M. (2004). First year medical student stress and coping in a problem-based learning medical curriculum. Med Educ, 38(5), 482-491. doi: 10.1046/j.13652929.2004.01814.x http://dx.doi.org/10.1046/j.1365-2929.2004.01814.x

Moust, J., Roebertsen, H., Savelberg, H., \& De Rijk, A. (2005). Revitalising PBL groups: Evaluating PBL with study teams. Education for Health, 18(1), 62-73. doi: 10.1080/13576280500042705

http://dx.doi.org/10.1080/13576280500042705 
Szabó Z, Harangi M, Nylander E, Ljungman A, Theodorsson A, Ahn H and Davidsson B. MedEdPublish 2015, 6: 17

http://dx.doi.org/10.15694/mep.2015.006.0017

Moust, J. H. C., Van Berkel, H. J. M., \& Schmidt, H. G. (2005). Signs of erosion: Reflections on three decades of problem-based learning at Maastricht University. Higher Education, 50(4), 665-683. doi: 10.1007/s10734-004-6371-z http://dx.doi.org/10.1007/s10734-004-6371-z

Pedhazur E. J., P. S. L. (1991). Measurement, Design and Analysis An Integrated Approach: Lawrence Erlbaum Associates Inc.

Ragab Ibrahim, N. K., Banjar, S., Al-Ghamdi, A., Al-Darmasi, M., Khoja, A., Turkistani, J., . . Basfar, W. (2014). Medical students preference of problem-based learning or traditional lectures in King Abdulaziz University, Jeddah, Saudi Arabia. Ann Saudi Med, 34(2), 128-133. doi: 10.5144/0256-4947.2014.128

Rawlings, H. R. (2012). Why Research Universities Must Change. Inside Higher Education.

Schwartz P, M. S., Webb G. (2001). Problem-Based Learning. Cases studies, Experience and practice. London: Kogan Page.

Seneviratne, R. D., Samarasekera, D. D., Karunathilake, I. M., \& Ponnamperuma, G. G. (2001). Students' perception of problem-based learning in the medical curriculum of the Faculty of Medicine, University of Colombo. Ann Acad Med Singapore, 30(4), 379-381.

Tarnvik, A. (2007). Revival of the case method: a way to retain student-centred learning in a post-PBL era. Med Teach, 29(1), e32-36. doi: 10.1080/01421590601039968

http://dx.doi.org/10.1080/01421590601039968

Woltering, V., Herrler, A., Spitzer, K., \& Spreckelsen, C. (2009). Blended learning positively affects students' satisfaction and the role of the tutor in the problem-based learning process: results of a mixed-method evaluation. Adv Health Sci Educ Theory Pract, 14(5), 725-738. doi: 10.1007/s10459-009-9154-6 http://dx.doi.org/10.1007/s10459-009-9154-6

\section{Table legend}

Table 1. Means and standard deviations for the four factors.

Table 2. Means and standard deviations for the four factors for the three stages in the medical program.

Table 3. Students' overall comprehension of PBL tutorial groups, aims and objectives.

Table 4. Students' overall appreciation of tutor competence and involvement.

Table 5. Student general opinion of PBL organization at our medical college.

Appendix 1. Post hoc test results 
Szabó Z, Harangi M, Nylander E, Ljungman A, Theodorsson A, Ahn H and Davidsson B. MedEdPublish 2015, 6: 17

http://dx.doi.org/10.15694/mep.2015.006.0017

\section{Supplemental Digital Content}

Appendix

Bonferroni post hoc tests

\section{Multiple Comparisons}

Bonferroni

\begin{tabular}{|c|c|c|c|c|c|c|c|}
\hline \multirow{2}{*}{$\begin{array}{l}\text { Depend } \\
\text { ent } \\
\text { Variable }\end{array}$} & \multirow[b]{2}{*}{ (I) Stage } & \multirow[b]{2}{*}{ (J) Stage } & \multirow{2}{*}{$\begin{array}{c}\text { Mean } \\
\text { Difference } \\
\text { (I-J) }\end{array}$} & \multirow[b]{2}{*}{ Std. Error } & \multirow[b]{2}{*}{ Sig. } & \multicolumn{2}{|c|}{$95 \%$ Confidence Interval } \\
\hline & & & & & & Lower Bound & Upper Bound \\
\hline \multirow[t]{6}{*}{ Factor 1} & Stage 1 & Stage 2 & , 10832 & ,05943 & ,207 &,- 0344 &, 2510 \\
\hline & & Stage 3 &, $38562^{*}$ & ,05336 &, 000 &, 2575 & ,5137 \\
\hline & Stage 2 & Stage 1 &,- 10832 & 05943 & ,207 &,- 2510 &, 0344 \\
\hline & & Stage 3 &, $27730^{*}$ & ,05214 & ,000 &, 1521 & ,4025 \\
\hline & Stage 3 & Stage 1 &,$- 38562^{*}$ & ,05336 &, 000 &,- 5137 &,- 2575 \\
\hline & & Stage 2 &,$- 27730^{*}$ & ,05214 &, 000 &,- 4025 &,- 1521 \\
\hline \multirow[t]{6}{*}{ Factor 2} & Stage 1 & Stage 2 &, $30342^{*}$ & ,07327 &, 000 &, 1274 & ,4794 \\
\hline & & Stage 3 & ,47887* & ,07020 &, 000 & ,3102 & ,6475 \\
\hline & Stage 2 & Stage 1 &,$- 30342^{*}$ & ,07327 &, 000 &,- 4794 &,- 1274 \\
\hline & & Stage 3 &, $17544^{*}$ & ,06765 & ,029 & ,0129 & ,3380 \\
\hline & Stage 3 & Stage 1 &,$- 47887^{*}$ & ,07020 &, 000 &,- 6475 &,- 3102 \\
\hline & & Stage 2 &,$- 17544^{*}$ & ,06765 & ,029 &,- 3380 &,- 0129 \\
\hline \multirow[t]{6}{*}{ Factor 3} & Stage 1 & Stage 2 &, $17663^{*}$ & ,06605 & ,023 & ,0181 & ,3352 \\
\hline & & Stage 3 &, $15302^{*}$ & ,05963 & ,032 & ,0099 & ,2962 \\
\hline & Stage 2 & Stage 1 &,$- 17663^{*}$ & ,06605 & 023 &,- 3352 &,- 0181 \\
\hline & & Stage 3 &,- 02361 & ,05909 & 1,000 &,- 1655 &, 1182 \\
\hline & Stage 3 & Stage 1 &,$- 15302^{*}$ & 05963 & ,032 &,- 2962 &,- 0099 \\
\hline & & Stage 2 & ,02361 & (05909 & 1,000 &,- 1182 &, 1655 \\
\hline
\end{tabular}


Szabó Z, Harangi M, Nylander E, Ljungman A, Theodorsson A, Ahn H and Davidsson B. MedEdPublish 2015, 6: 17 http://dx.doi.org/10.15694/mep.2015.006.0017

\begin{tabular}{|c|c|c|c|c|c|c|c|}
\hline \multirow[t]{6}{*}{ Factor 4} & Stage 1 & Stage 2 &,- 12349 &, 05360 & ,065 &,- 2521 &, 0052 \\
\hline & & Stage 3 &,$- 26891^{*}$ & ,04866 &, 000 &,- 3857 &,- 1521 \\
\hline & Stage 2 & Stage 1 & ,12349 & ,05360 &, 065 &,- 0052 &, 2521 \\
\hline & & Stage 3 &,$- 14542^{*}$ & ,04727 & ,007 &,- 2589 &,- 0320 \\
\hline & Stage 3 & Stage 1 & ,26891* & ,04866 &, 000 &, 1521 & ,3857 \\
\hline & & Stage 2 &, $14542^{*}$ & ,04727 & ,007 &, 0320 & ,2589 \\
\hline
\end{tabular}

*. The mean difference is significant at the 0.05 level. 